УДК 930.9.943.7.086 «1938-1939»

\title{
ІЛЬЮШИН І. І.
}

https://orcid.org/0000-0003-0288-8659

https://doi.org/10.33577/2313-5603.36.2021.207-230

\section{СТАВЛЕННЯ СРСР ДО ЧЕХОСЛОВАЦЬКОЇ КРИЗИ І ПИТАННЯ ПІДКАРПАТСЬКОЇ РУСІ (1938 - 1939 РР.)}

У статті на підставі нещодавно оприлюднених документів проаналізовано позицію керівництва СРСР стосовно центральноєвропейської (чехословацької) політичної кризи напередодні Другої світової війни. Доведено, що дії СРСР, спрямовані на підтримку Чехо-Словаччини, були продиктовані передусім наміром виконати свої зобов'язання відповідно до радянсько-чехословацького договору про взаємну допомогу і тим самим запобігти внаслідок можливого воєнного конфлікту серйозним змінам у європейській геополітичній конфігурації, які були б на шкоду Москві. 3 іншого боку, територіальній анексії Чехо-Словаччини, а у подалышому і остаточній іï ліквідації, сприяла політика Великобританії і Франції, уряди яких мало що зробили для того, аби зупинити німецьку експансію. Навпаки, підписавши Мюнхенську угоду, вони фактично визнали територію Центрально-Східної Свропи сферою переважаючих інтересів Третього рейху, а його претензії «природним процесом».

Ключові слова: Мюнхенська угода, німецька окупація, чехословацька криза, СРСР, Підкарпатська Русь.

Постановка проблеми та ї̈ актуальність. За глобальних змін у Центрально-Східній Європі кінця ХХ ст. - початку XXI ст. дослідники країн цього регіону піддали різкій критиці діï СРСР, спрямовані на укладення радянсько-німецького пакту про ненапад і наголосили навіть на тому, що Червона армія під гаслом надання допомоги Чехо-Словаччині восени 1938 р. вже тоді була здатною здійснити експансію щодо сусідніх народів. Зрозуміло, що в офіційній новітній російській історіографії такий погляд категорично заперечується. Заради детальнішого дослідження подій навколо так званої чехословацької кризи i спроби дати власну відповідь на поставлене питання автор використав чимало нових документів, зокрема 3 електронної Президентської бібліотеки імені Бориса Єльцина, і спробував переосмислити вже опрацьовані в історіографії матеріали.

Ільюшин Ігор Іванович, доктор історичних наук, професор кафедри гуманітарних дисциплін Національної академії керівних кадрів культури і мистецтв, м. Київ.

(C) Ільюшин I. I., 2021 
Аналіз попередніх досліджень $і$ публікащій. Пропонованій темі присвячено чимало досліджень і документальних публікацій, починаючи від тих, що з'явилися в роки «холодної війни» до останього часу, які виходили періодично в пострадянську добу у зв'язку з черговими ювілеями підписання Мюнхенської угоди (Год кризиса, 1990; Международный кризис, 2009; Мюнхен, 2018; Обнародованы, 2020). Ці напрацювання відображають широкий спектр уявлень про міжнародні відносини другої половини 1930-х років, Судетську кризу і Мюнхенську конференцію, їхній вплив на подальший хід історії, про джерела i історіографію досліджуваної проблеми (Невежин, 2000; Павленко, 2008; Kornat, 2002; Faber, 2009). Особливості політичного і національно-культурного розвитку Підкарпатської Русі в 20-30$\mathrm{x}$ p. XX ст. та карпатоукраїнське питання у зовнішній політиці європейских країн у період чехословацької кризи широко висвітлено у наукових працях вітчизняних дослідників (Вегеш, 1998, 2004; Богів i Задорожний, 1999; Кудряченко, 2019; Трофимович В. і Трофимович Л., 2013, 2019; Офіцинський, 2020 ma iн.). Незважаючи на це в ході дискусій навколо подій залишається чимало питань, зокрема: чи всі можливості використали західноєвропейські держави аби уникнути Мюнхенської угоди?; якою мірою ця угода підштовхнула СРСР до підписання пакту Ріббентропа-Молотова у серпні 1939 р.?; яку роль в цих подіях відіграли «малі» країни Свропи і навіть такі новоутворення як Карпатська Україна? тощо. Це свідчить про те, що ані у вітчизняній, ані в російській і західній історіографії остаточного погляду на ці події не сформовано, а тому історична дискусія про Мюнхенську угоду та ії наслідки ще не завершена.

Мета дослідження. На підставі архівних джерел (ГАРФ, РГВА, АВП РФ, ЦАМО РФ, РГАСПИ) та напрацювань вітчизняної і зарубіжної історіографії дослідити позицію керівництва СРСР в ході так званої центральноєвропейської (чехословацької) політичної кризи напередодні Другої світової війни та місце в тих подіях Підкарпатської Русі.

Виклад основного матеріалу. Наприкінці 1930-х років у Центрально-Східній Європі різко загострилася міжнародна ситуація, а світ опинився напередодні чергової війни. В епіцентрі 
суперечностей, які посилювалися щодня, опинилася ЧехоСловаччина. Країни-переможниці в Першій світовій війні Велика Британія і Франція - поступово втрачали керівні позиції в Європі, які вони займали впродовж усього міжвоєнного періоду. Натомість на головного міжнародного арбітра перетворювалася Німеччина, з якою були змушені рахуватись керівники усіх європейських держав.

Заручившись підтримкою Італії, Берлін все робив для того, щоб спочатку територіально обмежити Чехо-Словаччину (йшлося про приєднання до Третього рейху прикордонної області Судетенланд, де проживало близько 3 млн. німців), а потім і поглинути іiі. Одначасно зі здійсненням своїх намірів Берлін прагнув посприяти у вирішенні територіальних претензій до Чехо-Словаччини інших іiї сусідів, зокрема Угорщини і Польщі. Тому за результатами Мюнхенської конференції 29-30 вересня 1938 р. Прага, окрім передачі Судетської області на користь Німеччини, повинна була також задовольнити угорські та польські вимоги (Президентская библиотека, https://www.prlib.ru/item/1294382; https://www.prlib.ru/item/1294342; ГАРФ, Ф. P-9401. On. 2. Д. 102. Л. 51-58; РГВА, Ф. 116к. Оп. 8. Д. 48. Л. 1 - 4). Як зазначає польський дослідник Станіслав Жерко при обговоренні питання про польський ультиматум Чехо-Словаччині (Президентская библиотека, https://www.prlib.ru/item/1295330; РГВА, Ф. 308к. On. 12. Д. 275. Л. 9-11), лише один член уряду - віцепрем'єр Евгеніуш Квятковський - виступив проти, аргументуючи свою позицію тим, що це може зіпсувати імідж Польщі (Żerko, 2009: 171-189; Мюнхен, 2018; Польша, 2020).

На початку жовтня 1938 р. польська армія анексувала область Тєшинської Сілезії, де проживало близько 80 тисяч польського населення, і за яку поляки боролися ще у 1918 - 1920 роках (Президентская библиотека, https://www.prlib.ru/item/1294340; РГВА, Ф. 308к. Оп. 12. Д. 280. Л. 26-31). Такі дії, між іншим, дали радянському керівництву привід ще напередодні цієї події ставити перед польським урядом питання про порушення Польщею статті 2-ї радянсько-польського пакту про ненапад, укладеного між СРСР і Польщею 25 липня 1932 р., та його денонсацію (Документы, 1969: 363). Однак пізніше радянське 
керівництво вирішило не розривати договір, і 31 жовтня офіційно підтвердило, що він продовжує діяти. Про це було заявлено також в спільному радянсько-польському повідомленні від 27 листопада 1938 р (Известия, 27 ноября 1938; Марьина, 2007:27).

У свою чергу, Угорщина за наслідками першого Віденського арбітражу від 2 листопада 1938 р. домоглася передачі на свою користь південних районів Словаччини та Підкарпатської Русі, де компактно проживала угорська національна меншина. Водночас на вимогу словацьких та українських політичних кіл у жовтні 1938 р. Прага надала автономію Словаччині та Підкарпатській Русі, які відтак стали триєдиними частинами федеративної Другої Чехо-Словацької республіки, (що прийшла на зміну Першій після Мюнхена) (Офіичинський, 2020а: 145-150).

Територіальній анексії Чехо-Словаччини, а у подальшому i остаточній іiі ліквідації, також сприяла політика Великобританії і Франції, уряди яких мало що зробили для того, аби зупинити німецьку експансію. Навпаки, підписавши Мюнхенську угоду, вони фактично визнали територію Центрально-Східної Свропи сферою переважаючих інтересів Третього рейху, а його претензії «природним процесом».

Ще напередодні цієї події позицію голови британського уряду Невіла Чемберлена його найближчий помічник Хорас Вільсон під час розмови з радянським Повноважним представником в Лондоні Іваном Майським 10 травня 1938 р. охарактеризував наступним чином: «Чемберлен зважає на можливість німецької експансії в Центральній і Південно-Східній Європі і навіть на можливість поглинання Німеччиною (в тій чи іншій формі) низки невеликих центрально-європейських і балканських держав. Однак він вважає, що це менше зло, ніж війна з Німеччиною в найближчому майбутньому» (Документы, 1981: 91).

Не допоміг Чехо-Словаччині нейтралітет США. Державний секретар США Кордел Халл заявив на прес-конференції 30 вересня 1938 р., що результати Мюнхенської конференції викликають «загальне відчуття полегшення», і закликав подвоїти зусилля, спрямовані на мирний розвиток міжнародних відносин (Документы, 1979: 336-337).

По-суті, єдиним союзником Чехо-Словаччини в Свропі, готовим надати їй збройну підтримку, принаймні декларативно, виступив 
тоді СРСР. Під час промови у Женеві 21 вересня 1938 р. в Асамблеї Ліги Націй народний комісар закордонних справ СРСР Максим Литвинов заявив, що його країна має намір виконати всі зобов'язання відповідно до радянсько-чехословацького пакту про взаємну допомогу від 16 травня 1935 р., і що військове відомство СРСР готово негайно почати переговори 3 представниками Генеральних штабів Франції і Чехо-Словаччини, щоб намітити конкретні заходи для спільних дій $з$ Францією для надання Чехо-Словаччині необхідної допомоги усіма доступними шляхами (Известия, 22 сентября 1938).

Втім, ставлення країн Заходу до створення системи колективної безпеки було прохолодним. Радянсько-французький договір про взаємну допомогу від 2 травня 1935 р. був ратифікований Францією лише майже через рік. Сумніви викликало насамперед те, що СРСР не мав спільного кордону з Німеччиною і щоб виконати свої зобов'язання, довелося б радянським військам перетинати територію Польщі та Румунії. А ці держави боялися СРСР більше, ніж Німеччини, і категорично відмовлялись пропускати радянські війська. У французів і англійців склалося враження, що СРСР хоче втягнути ці країни у конфлікт 3 Німеччиною, а самому залишитись осторонь. Коли на Заході стали відомі наслідки репресій у радянській армії, то військовий союз з СРСР розцінили як маловартісний (Президентская библиотека, https://www.prlib.ru/item/12954695? mode=archive; АВП РФ, Ф. 059. On. 1. П. 277. Д. 1928. Л. 230-231).

У докладному аналітичному Огляді 2-го бюро Генерального штабу французької армії «Aide soviétique éventuelle à la TchécoSlovaquie» («Евентуальна радянська допомога Чехословаччині») від 15 вересня 1938 р. робився висновок про те, що «la puissance apparente de l'armée soviétique et le potentiel militaire soviétique ne correspondent pas à la situation réelle» («удавана міць СРCP i радянський військовий потенціал не відповідають реальному стану справ»). В останній частині «Огляду» «Aide qui pourrait être fournie par l'URSS de Tchécoslovaquie en cas d'agression allemande» («Допомога, яку міг би надати СРСР Чехословаччині у випадку німецької агресії») йшлося про те, що «L'aide soviétique peut être fournie plus sous forme de soutien aérien ou militaire que dans l'envoi de troupes au sol» («Радянська допомога, ймовірно, 
повинна надаватися у вигляді повітряної підтримки або військової техніки, а не у відправці підрозділів сухопутних військ») (Президентская библиотека, https://www.prlib.ru/item/ 1295332; РГВА, Ф. 198к. Оп. 9. Д. 18685. Л. 74-112).

В останні десятиріччя, за умов глобальних змін у ЦентральноСхідній Європі, історики країн цього регіону відійшли від традиційного для радянської і пострадянської історіографії трактування довоєнної політики Москви як такої, що мала миролюбний характер і була націлена винятково на те, аби стримати німецького агресора та віддалити європейську війну. Центральносхідноєвропейські дослідники піддали різкій критиці дії радянського керівництва, спрямовані на укладення радянсько-німецького пакту про ненапад («пакту Ріббентропа-Молотова») від 23 серпня 1939 р., а окремі з них навіть почали наголошувати на тому, що саме СРСР першим почав або спровокував цю війну.

В цьому ряду, на наш погляд, стоїть також факт приписування радянському керівництву наявності в нього намірів із започаткування наступальної війни в Свропі вже восени 1938 р. під час так званої чехословацької кризи. Тільки цим можна пояснити постановку, наприклад, польським істориком Мареком Дешчинським та цілком серйозні розмірковування над наступним питанням: «Чи була Червона армія здатною восени 1938 р. на те, аби під гаслом надання допомоги Чехо-Словаччині здійснити експансію щодо народів Центральної Свропи?» (Deszczyński, 2003: 202). Про передбачення в керівних колах Польщі існування загрози 3 боку СРСР восени 1938 р. пишуть також інші польські дослідники (Pepłoński, 1996: 297-310; Włodarkiewicz, 2002: 191-210; Kornat, 2002: 207; Kornat, 2010: 828).

На думку російського знавця цієї проблеми історика Володимира Невежина, кардинальна переорієнтація радянського керівництва 3 миролюбних позицій на експансіоністські сталася лише після укладення радянсько-німецького пакту про ненапад. Він доводить, що саме 3 цього моменту радянський пропагандистський апарат, ідеологічно забезпечуючи курс на зближення 3 нацистською Німеччиною, паралельно почав провадити кампанію 3 обгрунтування територіальних надбань Радянського Союзу. Полігоном для випробування такої пропаганди стала насамперед 
«польська кампанія» Червоної армії у вересні 1939 р., яка проходила під гаслами «забезпечення спокою та наведення порядку на колишніх польських землях». Під час «фінської кампанії» 1939 - 1940 рр. радянське керівництво остаточно відмовилось від «визвольних» гасел. Поки тривала на Заході «дивна війна» СРСР вбачав свого ворога ні в нацистській Німеччині, а в англійських і французьких «імперіалістах» - «підпалювачах війни», «польських панах», «бандах білофінів» і таке інше. Однак навесні 1941 р., стверджує В. Невежин, коли Німеччина стала реально погрожувати інтересам СРСР, радянське керівництво знову взяло на озброєння антифашистські і антинімецькі гасла, водночас розпочавши кампанію 3 підготовки країни та суспільства до «всесокрушающей» наступальної війни в Свропі (Невежсин, 1997; Мельтюхов, 2002; СССР, 2007; Чубарьян, 2008).

Отже, остаточної відповіді на поставлене питання, чи була Червона армія здатною восени 1938 р. на те, аби під гаслом надання допомоги Чехо-Словаччині здійснити експансію щодо народів Центральної Європи?, російські історики не дають. Втім, сьогодні в розпорядженні дослідників є чимало документів Генерального штабу РККА (Рабоче-крестьянской Красной армии) за 1938 рік, в яких докладно з'ясовується склад і військовий потенціал збройних сил можливих супротивників СРСР, a також викладаються основи стратегічного розгортання ра. В одному з них від 24 березня 1938 р., підготовленому Гендянських збройних сил на випадок війни як на заході, так і на сходіштабом РККА і підписаному його начальником, командармом 1-го рангу Борисом Шапошніковим, відверто стверджується, що «Радянський Союз повинен бути готовий воювати на двох фронтах: на заході проти Німеччини і Польщі, а частково проти Італії з можливим приєднанням до них лімітрофів, і на сході проти Японії.» (Президентская библиотека, https://www.prlib.ru/item/1296270; ЦАМО РФ, Ф. 16а. On. 2951. Д. 240. Л. 15-17, 121-150).

Та й важко повірити у миролюбний характер зовнішньополітичної діяльності СРСР на той час, коли він вже збройно протистояв блоку фашистських держав на території Іспанії, а в самій радянській країні тривали політично вмотивовані 
переслідування та вбивства. Проте, незважаючи на засудження з’їздом народних депутатів СРСР у грудні 1989 р. таємного додаткового протоколу до пакту Ріббентропа-Молотова (Постановление № 979-1, 1989), а також заяву у 2009 р. на той час голови російського уряду Володимира Путіна про «аморальний характер пакту» і його «безперспективність 3 точки зору практичної реалізації» (Putin, 2009), більшість російських науковців продовжують вважати, що в самому договорі про ненапад «нічого ганебного не було» і що він був дійсно превентивною мірою, яка мала на меті віддалити напад Німеччини на СРСР (Советско-польские, 2004; Международныий кризис, 2009).

Водночас вони визнають, що договір відкривав «зелене світло» для гітлерівської агресії проти Польщі, але так само, як Мюнхенська угода рік тому посприяла Гітлерові реалізувати його реваншистські задуми стосовно Чехо-Словаччини. Лише поодинокі російські дослідники заперечують такий підхід. Так, наприклад, Марк Солонін стверджує, що якщо навіть визнати, що керівники Великобританії і Франції здійснили велику помилку, уклавши Мюнхенську угоду, то ці країни не анексували жодного клаптика чехословацької території, в той час як наслідком пакту Ріббентропа-Молотова стало захоплення Червоною армією більше ніж половини Польщі (Солонин, 2011).

До того ж, Едуард Даладьє і Невіл Чемберлен, укладаючи Мюнхенську угоду, сподівалися на збереження загального миру, тоді як Й. Сталін, погоджуючись на радянсько-німецький пакт про ненапад, скорше за все вже знав, що Польща в найближчий час буде атакована Німеччиною і що Гітлеру після «Мюнхена» довіряти не варто. У спецповідомленнях Розвідуправління РККА вже з другої половини березня 1939 р. йшлося про нанесення удару по Польщі як про один 3 ймовірних подальших напрямів німецької агресії на сході Свропи (Президентская библиотека, https://www.prlib.ru/item/1296557; РГВА, Ф. 33987. On. 3а. Д. 1237. Л. 202-204). 3 квітня 1939 р. у Директиві Верховного головнокомандування Вермахту про підготовку до війни на 1939/40 рр. по плану «Вайс» (проти Польщі) стверджувалося, що «Підготовка повинна здійснюватися таким чином, щоб реалізація була можлива в будь-який час, починаючи від 
01.09.[19]39 р.» (Президентская библиотека, https://www.prlib.ru/item/1295913; https://www.prlib.ru/item/1294289; https://www.prlib.ru/item/1295895; ГАРФ, Ф. Р-7445. On. 2. Д. 166. Л. 237-247).

Переконання поляків у тому, що Польща була першою жертвою війни і понесла найбільші втрати в перерахунку на одного мешканця, непорушні в національній пам'яті про XX сторіччя (Kornat, 2015; Яжборовская, 2015). Не менш усталеними є переконання росіян у тому, що «перемога у Великій Вітчизняній війні принесла радянському народу позбавлення від біологічного винищення». Водночас росіяни, як одні із переможців в тій війні, претендують на право не співставляти свою національну пам'ять 3 європейськими стандартами. Справедливість цієї тези не піддається сумніву в російському суспільстві, але культ перемоги у війні безумовно ускладнює росіянам критичний аналіз дій Сталіна і радянської доби загалом (Ассман, 2014: 165).

У 2020 році на порталі Президентської бібліотеки імені Бориса Єльцина в Москві до 75-ї річниці Перемоги СРСР у війні оприлюднені понад 1700 архівних документів, фотографій, фрагментів кінохроніки, присвячені передісторії Другої світової війни. Перша частина колекції хронологічно охоплює період від січня 1933 р. до кінця серпня 1939 р. Майже половина з цих матеріалів публікуються вперше. Всі документи оцифровані і мають опис російською і англійською мовами. Матеріали різноманітні за своїм складом, походженням і авторством. Втім $є$ те, що їх об’єднує. Як заявила директор історико-документального департаменту Міністерства закордонних справ Росії Надія Баринова «Невипадково проект почався з документів довоєнного періоду. Зараз ми бачимо спроби звинуватити СРСР нарівні 3 Німеччиною у розв'язанні Другої світової війни. Це категорично неможливо допустити, документи буквально кричать, протестуючи проти цієї політизованої версії» (Обнародованы, 2020).

Повертаючись до подій осені 1938 р., слід зазначити, що дії СРСР, спрямовані на підтримку Чехо-Словаччини, були продиктовані всеж-таки передусім наміром виконати свої зобов'язання відповідно до радянсько-чехословацького договору про взаємну допомогу і тим самим запобігти внаслідок можливого воєнного конфлікту серйозним змінам у європейській 
геополітичній конфігурації, які були б на шкоду Москві. I хоча, наприклад, в повоєнному офіційному академічному виданні «История Великой Отечественной войны Советского Союза 1941-1945 гг.» стверджувалось, що: «Радянський уряд був рішуче налаштований... захищати ЧСР навіть у випадку, якщо б французький уряд ухилився від своїх зобов'язань, а Польща і Румунія перешкоджали б діям СРСР» (История, 1960: 147), цю тезу варто розцінювати лише як пропагандистський маневр.

За обставин, коли польський уряд зробив усе, аби не допустити можливості проходження радянських дивізій через територію Румунії на допомогу Чехо-Словаччині (через тиск на Бухарест), не кажучи вже про заблокування такої можливості через власну територію (не зупиняюсь тут на аналізі причин цього, з погляду тодішньої Варшави цілком історично обгрунтованих), де в критичні дні вересня 1938 р. на Волині почались великі маневри польських збройних сил, що передбачали ту саму мету, Москва не могла серйозно ставити питання про надання дієвої збройної підтримки своєму союзникові в Центрально-Східній Європі (Президентская библиотека, https://www.prlib.ru/item/1294022; РГАСПИ, Ф. 17. On. 166. Д. 592. Л. 46).

Показовою стала реакція на промову наркома СРСР Литвинова 21 вересня 1938 р. в Асамблеї Ліги Націй німецької преси. Особливу злість Берліна викликала заява Литвинова про готовність СРСР таки виконати свої зобов'язання стосовно ЧехоСловаччини. Коментуючи виступ радянського наркома, газета «Дойче Альгемайне Цайтунг» від 28 вересня 1938 р. зазначала: «Підтверджуючи у своєму виступі кампанію, спрямовану Радянським Союзом проти Німеччини, Литвинов і на пленумі намагався налаштувати Лігу проти «Третьої імперії» 3 метою спровокувати світову війну... Позиція Британії та Франції демонструє ізоляцію Радянського Союзу. Судячи з усього, Радянський Союз має намір програти гру, яку він почав 20 років тому разом з Бенешем.» (Президентская библиотека, https://www.prlib.ru/item/1294367; ГАРФ, Ф. Р-4459. On. 28. Д. 273. Л. 56).

За тиждень до конференції у Мюнхені, 23 вересня 1938 р., М. Литвинов у телеграмі з Женеви сповіщав Народний комісаріат закордонних справ СРСР, а фактично й Йосипа Сталіна: 
«3 огляду на те, що європейська війна, в яку ми будемо втягнуті, не в наших інтересах і що потрібно зробити все, щоб запобігти цьому, я ставлю питання, чи не повинні ми оголосити хоча б часткову мобілізацію і повести таку кампанію в пресі, яка змусить Гітлера і Бека повірити у можливість великої війни за нашої участі» (Документы, 1977: 520).

Після укладення 30 вересня Мюнхенської угоди ситуація принципово змінилась. Рішення, прийняті в Мюнхені керівниками урядів чотирьох европейських країн, остаточно паралізували можливості втручання Радянського Союзу в чехословацьке питання в самому широкому значенні. Москва інтерпретувала «Мюнхен» як згоду Великобританії і Франції з Гітлером на знешкодження союзника СРСР в Центрально-Східній Свропі, засудила Чехо-Словаччину за відмову від опору, висловила побоювання, що експансія Німеччини в подальшому може бути спрямована в бік Радянського Союзу (Известия, 10 ноября 1938). Втім, небезпека загальноєвропейської війни на якийсь час була віддалена.

Проте, була ще одна причина, яка змусила Москву пізніше переглянути певною мірою своє попередне ставлення до чехословацької кризи восени 1938 р. Нагадаємо, що Чехо-Словаччина виникла не лише в результаті угоди чехів і словаків в Піттсбурзі, але і внаслідок підписаної в м. Скрентоні (штат Пенсільванія, США) у листопаді 1918 р. угоди з чеськими лідерами емігрантів з Закарпаття, які погодилися на включення своєї батьківщини до складу нової Чеської держави за умови надання їй автономії. Сен-Жерменський договір від 10 вересня 1919 р. також зобов'язував Чехо-Словаччину утворити на території русинів на південь від Карпат у визначених союзними країнами кордонах автономну одиницю у складі чехословацької держави та надати їй якнайбільший ступінь самоврядування (Субтельний, 1993: 387). Проте реальний автономний статус Карпатської України, передбачений як Сен-Жерменським договором 3 Чехо-Словаччиною, так i Тріанонським договором від 4 червня 1920 р. 3 Угорщиною, фактично не був забезпечений чехословацьким урядом.

Питання Підкарпатської Русі (саме під такою назвою Закарпаття входило до федеративної Чехо-Словаччини в 1919 -1938рр.) 
як і «українське питання» взагалі від самого початку почало відігравати суттєву роль у взаєминах Праги із сусідніми державами, насамперед, з Радянською Росією і Польщею. В сучасній польській історіографії зокрема поширений погляд, що чеські керівники загравали з Москвою і трактували східний кордон Польщі на р. Збруч як тимчасовий. Наприклад, Марек Камінський стверджує, що, як вважав міністр закордонних справ чехословацького уряду Едвард Бенеш, Східна Галичина або східна частина австрійської Галичини мала відійти від Польщі до Радянської Росії. Тоді Чехо-Словаччина могла отримати спільний 3 нею кордон у східних Карпатах (Kamiński, 2001: 434).

У сучасній чеській історіографії такий погляд категорично заперечується. Наприклад, Ярослав Валента звинуватив М. Камінського, автора книги «Польсько-чеський конфлікт 1918 1921 рр.» у тому, що він сприйняв на віру вигадку польських журналістів, ініційовану в 1919 р. Варшавою і Будапештом, про те, нібито Чехо-Словаччина прагнула до відірвання від Польщі Східної Галичини і встановлення через цю територію спільного чесько-українсько-російського кордону. Він доводить, що тогочасні керівники Чехо-Словаччини - президент Томаш Масарик, прем’єр Карел Крамарж, міністр закордонних справ Е. Бенеш не симпатизували українській справі в Східній Галичині, а навпаки готові були активно підтримувати польську позицію щодо неї. Він також стверджує, що із Західно-Українською Народною Республікою (ЗУНР) впродовж 1918 - 1919 рр. Прага мала лише торгові відносини, оскільки вона лише зі Східної Галичини могла на той час отримувати нафту (Valenta, 2003: 227-228).

Втім, М. Камінський в листі до редакції часопису «Dzieje najnowsze» («Новітня історія») наполягав на тому, що Е. Бенеш навіть уклав угоду з керівником ЗУНР Свгеном Петрушевичем про відірвання Східної Галичини від Польщі і оформлення унії 3 Чехо-Словаччиною. На думку польського історика, саме ця обставина підштовхнула в свою чергу Варшаву ініціювати пізніше кампанію, спрямовану на відірвання від Чехії Словаччини i Карпатської Русі (Kamiński, 2003: 229-231).

Наведений вище приклад полеміки між сучасними чеськими i польськими дослідниками щодо ролі, яку відіграли у відносинах 
між Чехо-Словаччиною і Польщею Радянська Росія і так зване «українське питання» свідчить про те, що заторкнута проблема залишається болісною для обох народів і сьогодні. Тут також зазначимо, що найкраще позицію тодішнього чеського уряду в цій справі висвітлюють циркулярні телеграми, надіслані до чеських дипломатичних представництв в інших країнах, самого міністра закордонних справ, а 3 кінця 1935 р. Президента ЧехоСловаччини Е. Бенеша (Cirkulární, 2002).

Польська історіографія одностайна також в оцінці неприхильної за характером позиції Праги щодо Варшави в наступний період (під час спільного польсько-українського військового походу проти Радянської Росії у квітні-травні 1920 р., боїв поляків з більшовицькими військами на Віслі в серпні 1920 р.), наслідком якої стало насильницьке розв'язання на користь ЧехоСловаччини чесько-польської територіальної суперечки навколо Тешинської Сілезіï (Kamiński, 2001: 6).

На думку колишнього прес-аташе польської амбасади в Празі Казімежа Вежбянського, чехословацький уряд відхиляв усі пропозиції Варшави про укладення угоди про політичне та військове співробітництво. На його погляд, чеські керівники вважали міжвоєнну Польщу «Балканами Центральної Свропи», тобто країною, яка мала територіальні непорозуміння з Німеччиною і СРСР, а тому за наказом останнього не бажали погоджуватися на таке співробітництво. На думку К. Вежбянського, якщо б не тиск на Е. Бенеша Москви, яка не була зацікавлена у військовому союзі між Польщею і Чехо-Словаччиною, укладення такого союзу між країнами могло підштовхнути Францію до більш рішучої їх підтримки, а отже все це в сукупності зайвий раз змусило б Гітлера і Сталіна утриматися від агресивних кроків щодо країн Центрально-Східної Свропи (Wierzbiański, 1986: 79-88).

Заради історичної справедливості важливо зазначити, що i польські керівники важали Чехо-Словаччину «штучним витвором» у поверсальській Європі. У листі від 19 вересня 1938 р. міністра закордонних справ Юзефа Бека послу Польщі в Німеччині Юзефу Ліпському серед директивних вказівок стосовно розмов з Гітлером була й така: «Чехословацьку республіку ми вважаємо штучним витвором, який задовільняє деякі комбінації, але не 
відповідає дійсним потребам і здравим правам народів Центральної Свропи» (Документы, 1969: 361).

Добре відомо, що з відірвання Німеччиною від Чехо-Словаччини 1 жовтня 1938 р. Судетів і послаблення у зв'язку з цим позицій празького уряду скористалися словацькі і підкарпатські лідери, які проголосили автономію своїх країв. 11 жовтня чехословацький уряд під тиском Німеччини дав дозвіл на створення уряду автономної «Закарпатської України». Третій рейх виступив тоді за автономію Закарпатської України в складі Чехо-Словаччини і не підтримав польсько-угорські плани щодо приєднання до Угорщини всієї Закарпатської України (Год кризиса, 1990: 46).

22 листопада 1938 р. автономія Карпатської України була схвалена празьким парламентом, що одразу стало причиною неспокою в декількох країнах. Насамперед активізацією українського національного руху був наляканий польський уряд, який прагнув підіграти Угорщині в іiі планах включення Закарпаття до свого складу. На думку польських і угорських керівників, встановлення спільного польсько-угорського кордону ліквідувало б джерело українського заколоту. Тому під час короткого існування Карпатської України польські й угорські військові частини чинили постійні провокації на іiї кордоні (Samuś, Badziak, Matveev, 1998: 326; Морозов, 2004; Президентская библиотека, https://www.prlib.ru/item/1294839; АВП РФ, Ф. 059. On. 1. П. 281. Д. 1954. Л. 203).

Занепокоєння багатьох європейських держав викликала також орієнтація уряду автономної Карпатської України на Німеччину єдину країну, яка ніби «пообіцяла українцям свій протекторат». Про це, зокрема, повідомлялося на шпальтах карпатоукраїнської газети «Нова свобода», яка спочатку друкувалася в Ужгороді, а пізніше в Хусті, куди евакуювалися всі чехословацькі органи влади, установи й організації відповідно до рішень Віденського арбітражу 2 листопада 1938 р. («Нова свобода», 18 жовтня 1938; 23 жовтня 1938; 22 листопада 1938). Голова уряду Августин Волошин плекав утопічні сподівання на прокарпатоукраїнські сантименти тодішнього канцлера Німеччини Адольфа Гітлера. Тому не випадково, хоча і даремно, британські і французькі правлячі кола потрактували «підтримку» Гітлером Карпатської 
України як перший крок на шляху створення Німеччиною васальної Української держави (Кудряченко, 2019; 283).

Про уявлення, що панували, зокрема, у англійців стосовно подібних планів Гітлера інформував Кремль Повноважний представник СРСР у Великобританії Іван Майський у грудні 1938 р.: «План Гітлера - повернути «коридор» і Сілезію і відірвати від Польщі ії українську частину, об'єднати останню 3 Прикарпатською Україною і створити з обох васальну українську державу на зразок Чехословаччини. Це найближче завдання. У більш віддаленому майбутньому Гітлер, можливо, думає про те, щоб діяти проти Радянської України, але тепер він не наважиться цього зробити» (Документы, 1977: 661-662).

Можливість перетворення Закарпаття в зародок більшої самостійної української держави налякала також керівництво СРСР та породила додаткову напруженість у взаєминах між Берліном і Москвою. Надання автономії Закарпатській Україні було використано німецькою пресою для організації гучної кампанії за приєднання до Закарпатської України Радянської України. Формальна підтримка Німеччиною ідеї створення на основі Карпатської України Великоукраїнської держави, яку плекали як в уряді А. Волошина, так і в керівництві Організації українських націоналістів (ОУН), була спрямована не лише на шантаж Польщі, Угорщини, але і СРСР (Вегеш, 1998:16; Грищак, 2000: 202; Кудряченко, 2019: 285).

В численних шифротелеграмах тимчасового повіреного в справах СРСР в Німеччині Григорія Астахова до наркомату закордонних справ СРСР йшлося про активне обговорення в нацистських колах Німеччини «української проблеми» та шляхів іiі вирішення. В одній з них від 14 грудня 1938 р. Астахов, зокрема, інформував: «Рішення «проблеми» розглядається в площині створення «єдиної» України 3 усіх частин, в тому числі і Радянської... Ми могли б довести своє право на Карпатську Україну з набагато більшою підставою, ніж остання на нашу» (Трофимович В. і Трофимович Л., 2019:257; Президентская библиотека, https://www.prlib.ru/item/1298150; АВП РФ, Ф. 059. Оп. 1. П. 271. Д. 1882. Л. 298).

У повідомленні від 21 грудня 1938 р. нарком внутрішніх справ СРСР Лаврентій Берія з посиланням на відомості, отримані 
3 кіл італійського міністерства закордонних справ, відверто інформував Й. Сталіна про німецькі плани інтервенції проти СРСР: «Під час останнього візиту Ріббентропа до Риму з'ясувалося, що італійські помірні тенденції щодо Радянського Союзу не знайшли відгуку у Берліні. Гітлер у цьому питанні повністю солідарний з японцями. 3 нинішньої Чехословаччини і Карпатської України він збирається зробити плацдарм для кампанії проти Радянського Союзу... 3 цією метою він, нібито, не зупиниться перед порушенням румунських кордонів, а в разі необхідності - i польських» (Президентская библиотека, https://www.prlib.ru/item/1295766).

У своїй промові на XVIII з'їзді ВКП (б) 10 березня 1939 р. Сталін не міг не зупинитися на цій проблемі. Він піддав критиці ідею приєднання Радянської України з 30 млн. людей до краю 3 населенням всього 700 тис. мешканців, потрактувавши ії як приєднання «слона к козявке». Втім ця критика була спрямована не стільки проти німецького керівництва, скільки проти англофранцузської і північно-американської преси, яка, як заявив Сталін, «волала, що німці йдуть на Радянську Україну, що у них тепер в руках так звана Карпатська Україна [...], що німці ще навесні цього року приєднають Радянську Україну [...] до так званої Карпатської України. Схоже, що цей підозрілий шум мав на меті підняти лють Радянського Союзу проти Німеччини, отруїти атмосферу і спровокувати конфлікт з Німеччиною за відсутності будь-яких на то причин» (XVIII съезд, 1939: 8-9; Трофимович В. і Трофимович Л., 2019:260).

В німецькому керівництві сприйняли виступ Сталіна як відмову Радянського Союзу від претензій на цю частину української території. Гітлер одночасно з остаточним поглиненням Німеччиною Чехо-Словацької республіки 15 березня 1939 р. погодився також на окупацію Закарпаття Угорщиною, яка 24 лютого приєдналася до Антикомінтернівського пакту (Президентская библиотека, https://www.prlib.ru/item/1295524; РГВА, Ф. 500к. On. 1. Д. 962. Л. 186-187; https://www.prlib.ru/item/1294759; АВП РФ, Ф. 06. Оп. 1. П. 7. Д. 62. Л. 10-13). Будапешт ультимативно зажадав від керівництва Чехо-Словаччини передати Закарпатську Україну Угорщині. 14 березня 1939 р. Сойм Карпатської України 
проголосив незалежність краю, але вже наступного дня угорські війська зайняли територію Закарпатської України (повністю до 18 березня 1939 р.) (Офіициський, 2020б: 60-73).

В особистій ноті від 18 березня 1939 р. нарком закордонних справ СРСР М. Литвинов повідомив послу Німеччини в СРСР Фридриху-Вернеру фон дер Шуленбургу про неможливість визнання радянським урядом включення Чехії до складу Третього рейху. В ноті, зокрема, стверджувалося, що: «Чехословацький президент г. Гаха, підписавши берлінський акт 15-го цього місяця, не мав на те жодних повноважень від свого народу і діяв всупереч статтям 64-й і 65-й чехословацької конституції і волі свого народу. Отже, зазначений акт не може вважатися таким, що має юридичну силу...Наведені вище зауваження повністю стосуються і зміни статусу Словаччини в дусі підпорядкування останньої Німецькій імперії, що не виправдано жодним волевиявленням словацького народу...Дії німецького уряду дали поштовх до грубого вторгнення угорських військ в Карпатську Русь і до порушення елементарних прав іiі населення». На переконання радянського уряду, дії німецького керівництва не лише не усували небезпеку загальному миру, а, навпаки, значно ії посилювали, порушуючи стабільність у Центральній Свропі (Президентская библиотека, https://www.prlib.ru/item/1293982: АВП РФ, Ф. 06. Oп. 1. П. 7. Д. 62. Л. 14-16).

На завершення важливо зауважити, що надії тих політиків, які прагнули до встановлення спільного кордону між ЧехоСловаччиною і Радянським Союзом, після завершення Другої світової війни справдилися. Проте разом з цим над ЧехоСловаччиною, як і всією Центрально-Східною Європою, було встановлено радянський диктат. Навіть незавершений ще на той час польсько-чеський територіальний конфлікт навколо Заолжя зараз довелося розв'язувати не в Празі або Варшаві, і не за участі західних країн, а у Москві за радянського посередництва. Остаточно «історія Мюнхена» завершилась лише в 1974 р. договором між Федеративною Республікою Німеччини і Чехословаччиною.

Висновки. Таким чином, доведено, що під час центральноєвропейської політичної кризи напередодні Другої світової війни дії 
керівництва СРСР, спрямовані на підтримку Чехо-Словаччини, були продиктовані передусім наміром виконати свої зобов'язання відповідно до радянсько-чехословацького договору про взаємну допомогу і тим самим запобігти внаслідок можливого воєнного конфлікту серйозним змінам у європейській геополітичній конфігурації, які були б на шкоду Москві. Водночас важко повірити лише у миролюбний характер зовнішньополітичної діяльності СРСР у той час, коли він вже збройно протистояв блоку фашистських держав на території Іспанії, а в самій радянській країні тривали політично вмотивовані переслідування та вбивства.

3 іншого боку, територіальній анексії Чехо-Словаччини, а у подальшому і остаточній іiі ліквідації, сприяла політика Великобританії і Франції, уряди яких мало що зробили для того, аби зупинити німецьку експансію. Навпаки, підписавши Мюнхенську угоду, вони фактично визнали територію Центрально-Східної Європи сферою переважаючих інтересів Третього рейху, а його претензії «природним процесом».

Цілковите поглинення Німеччиною Чехо-Словацької республіки і захоплення Карпатської України Угорщиною, з одного боку, остаточно паралізували можливості втручання Радянського Союзу в це питання, але, з іншого, дали підстави для поступової переорієнтації його зовнішньої політики в напрямку радянськонімецького зближення.

Автор свідомий того, що жодні інтерпретації історичних фактів не можна декретувати. А тому подальше дослідження пропонованої проблематики із залученням нововідкритих архівних матеріалів із російських архівосховищ представляється йому цілком можливим і навіть доволі перспективним.

\section{Використані посилання}

Архив внешней политики Российской Федеращии (АВП РФ).

Ассман А. (2014) Длинная тень прошлого: мемориальная культура и историческая политика. Москва, Новое литературное обозрение. 323 с.

Богів О., Задорожний В. (1999) Карпатська Украӥна (Підкарпатська Русь) у міжнародних відносинах (травень 1938 - березень 1939). Ужгород, Патент. 1999. $80 \mathrm{c}$.

Вегеш М. (1998) Закарпаття в контексті центральноєвропейської політичної кризи напередодні Другої світової війни. Автореферат дисертаиії на здобуття 
наукового ступеня доктора історичних наук. Київ, Інститут історії України НАН України. $30 \mathrm{c}$.

Вегеш М. (2004) Августин Волошин і Карпатська Украӥна. Львів, ЗУКЦ. 414 с.

Документы внешней политики СССР (1977 ) / Т. XXI. 1 января-31 декабря 1938 г. Комиссия по изданию дипломатических документов при Министерстве иностранных дел СССР А. Л. Громыко (Председатель комиссии), И. И. Земсков (заместитель Председателя), Г. К. Деев (ответственный секретарь). Москва, Политиздат. 792 с.

Документы и материаль кануна Второй мировой войны 1937-1939: в 2-х т. Т. 1. Ноябрь 1937 г. - декабрь 1938 г. МИД СССР (1981) Москва, Политиздат. $306 \mathrm{c}$.

Документы и материаль по истории советско-польских отношений Т. 6: 1933-1938 гг. (1969) Москва, Институт славяноведения Академии Наук СССР. 432 c.

Документы по истории мюнхенского сговора, 1937-1939 (1979). Москва, Политиздат. $471 \mathrm{c.}$

Год кризиса 1938-1939. Документы и материалы в двух томах. Т. 1. 29 сентября 1938 г. - 31 мая 1939 г. (1990) Москва, Политиздат. 562 с.

Государственный архив Российской Федераџии (ГАРФ).

Грицак Я. (2000) Нарис історії України. Формування модерної украӥнської нації XIX-XX століття. Київ, Генеза. 360 с.

Жерко С. (2009) Польша и судетский кризис 1938 г. Мюнхенское соглашение 1938 года: история и современность. Материалы междунар. науч. конф. Москва, 15-16 октября 2008 г. Москва, Наука. С. 171 - 189.

История Великой Отечественной войны Советского Союза 1941-1945 г2. (1960) (в 6-ти т.). Т. 1. Подготовка и развязывание войны империалистическими державами. Москва, Воениздат. 600 с.

Корнат М. (2015) Польская политика памяти после 1989 г: проблемы, дилеммы, постулаты. Россия и Польща: История общая и разобщенная. Москва, Аспект Пресс. С. 23-59.

Кудряченко А. (2019) Карпатська Україна у планах гітлерівської Німеччини. Русин. № 57. С. $271-293$.

Марьина В. (2007) Советский Союз и чехо-словачкий вопрос во время Второй мировой войны. 1939-1945 г2. Кн. 1. 1939-1941 г2. Москва, Индрик. 448 с.

Международный кризис 1939 года в трактовках российских и польских историков (2009) Москва, Аспект Пресс. 479 с.

Мельтюхов М. (2002) Упущенный шанс Сталина: Советский Союз и борьба за Европу, 1939-1941 ге. (Документы, факты, суждения). Москва, Вече. 608 с.

Морозов С. (2004) Польско-чехословачкие отношения, 1933-1939. Что скрывалось за политикой «равноудаленности» министра Ю. Бека? Москва: Издательство Московского университета, 527 с.

Мюнхен 1938: Падение в бездну Второй мировой войны. (2018) Москва, Кучково поле. 272 с.

Невежин В. (1997) Синдром наступательной войны: Советская пропаганда в преддверии «священных боёв», 1939-1941 ге. Москва, Аиро-ХХ, 286 с. 
«Обнародовань советские документы о Третьем рейхе» (2020) URL: https://lenta.ru/news/2020/05/21/docs/. (Дата звернення 27.07.2020).

Офіцинський Р. (2020а). Актуальне про угорську агресію на Закарпаття (1938-1944). В: Офіцинський Р. Карпатська Україна: історичні есе. Ужгород, Timpani. C. 145-150.

Офіцинський Р. (2020б). Окупація та анексія Карпатської України (березеньлипень 1939) В: Офіцинський Р. Карпатська Украӥна: історичні есе. Ужгород, Timpani. C. $60-73$.

Павленко О. (2008) Историографический образ «Мюнхена 1938 года» и проблемы исторической памяти. Мюнхенское соглашение 1938 года: История и современность: материалы междунар. науч. конф, 15-16 октября 2008, Москва, Наука. С. 388-408.

Польша в борьбе за Восточную Европу 1920-2020. (2020) Москва, Кучково поле, $176 \mathrm{c}$.

Постановление Съезда народных депутатов от 24 декабря 1989 г. № 979-1. О политической и правовой оченке советско-германского договора о ненападении om 1939 года. URL: https://www.lawmix.ru/docs_cccp/1241. (Дата звернення 22.07.20).

Президентская библиотека им. Б. Н. Ельциина.

Российский государственный архив социильно-политической истории (РГАСПИ)

Российский государственный военный архив (РГВА).

Советско-польские отношения в политических условиях Европь 30-х годов ХХ столетия. (2004) Москва, Наука. 231 с.

Солонин М. (2011) Москва и «Мюнхен». Военно-промылиленный курьер. № 8 (374), 2 марта 2011; № 9 (375), 9 марта 2011; № 10 (376), 16 марта 2011.

СССР, Восточная Европа и Вторая мировая война, 1939-1941: дискуссии, комментарии, размышления (2007) Москва, Наука. 486 с.

Субтельний О. (1993) Україна: історія. Київ, Либідь. 720 с.

XVIII съезд Всесоюзной Коммунистической партии (б). 10-21 марта 1939 2. Стенографический отчет (1939) Москва, Госполитиздат. 737 с.

Трофимович В., Трофимович Л. (2019) Карпатоукраїнський аспект зовнішньої політики європейских країн у період чехословацької кризи (1938-1939рр.) Русин. № 57. С. 251-270.

Трофимович Л., Трофимович В. (2013) Небезпечне суперництво... Украйнське питання в зовнішній політиці Польщฺі та Радянського Союзу 1938-1939 рр. Рівне, Волинські обереги. 234 с.

Центральный архив Министерства обороны Российской Федерации (ЦАМО РФ)

Чубарьян А. (2008) Канун трагедии: Сталин и международный кризис, сентябрь 1939 - июнь 1941 года. Москва, Наука. 484 с.

Яжборовская И. (2015) Польша новейшего времени в исторической политике СССР и современной России В: Россия и Польша. История общая и разобщённая. Москва, Аспект Пресс. С. 230-247.

Cirkulárni telegramy 1920-1935. (2002) Z dokumentů Archivu Ministerstwa zahraničnich věci České republiky. Praga, Společnost Edvarda Beneše. 277 s. 
Deszczyński M-P. (2003) Ostatni egzamin. Wojsko Polskie wobec kryzysu czechostowackiego 1938-1939. Warszawa, Neriton. $202 \mathrm{~s}$.

Faber D. (2009) Munich: the 1938 appeasement crisis. London, Simon \& Schuster. 518 p.

Kamiński M-K. (2001) Konflikt polsko-czeski 1918-1921. Warszawa, Neriton. 476 s.

Kamiński M-K. (2003) List do Redakcji «Dziejów Najnowszych». Dzieje Najnowsze. № 4. S. 229-231.

Kornat M. (2002) Polska 1939 roku wobec paktu Ribbentrop-Mołotow: problem zbliżenia niemiecko-sowieckiego w polityce zagranicznej II Rzeczypospolitej. Warszawa, Polski Instytut Spraw Międzynarodowych. 808 s.

Kornat M. (2010) Stan badań na temat stosunków polsko-radzieckich. W: Białe plamy - czarne plamy: Sprawy trudne w relacjach polsko-rosyjskich (1918-2008), Warszawa, Polski Instytut Spraw Międzynarodowych. S. 793-841.

Nevezhin W. (2000) Tajne plany Stalina: propaganda sowiecka $w$ przededniu wojny z Trzecia Rzesza 1939-1941. Kraków, Arcana. $292 \mathrm{~s}$.

Pepłoński A. (1996) Wywiad Polski na ZSRR. 1921-1939. Warszawa, Bellona. $392 \mathrm{~s}$.

Putin W. (2009) Karty historii - powód do wzajemnych pretensji, czy podstawa pojednania i partnerstwa? URL: https://wyborcza.pl/1,75399,6983945 (Дата звернення 24.07.2020).

Samuś P., Badziak K., Matwiejew G. (1998) Akcja «Lom». Polskie działania dywersyjne na Rusi Zakarpackiej w świetle dokumentów Oddziału II Sztabu Głównego WP. Warszawa, Adiutor. $327 \mathrm{~s}$.

Valenta J. (2003) List do Redakcji «Dziejów Najnowszych». Dzieje najnowsze. № 4. S. 227-228.

Wierzbiański K. (1986) Benesz a Polska. Zeszyty Historyczne. № 76. S. 79-88.

Włodarkiewicz W. (2002) Przed 17 września 1939 roku: radzieckie zagrożenie Rzeczypospolitej w ocenach polskich naczelnych władz wojskowych 1921-1939. Warszawa, Neriton. 317 s.

\section{References}

Archives of the Foreign Policy of the Russian Federation (AVPRF). (rus).

Assmann A. (2006) Der lange Schatten der Vergangenheit: Erinnerungskultur und Geschichtspolitik [Long Shadow of the Past: Culture of Memory and Politics of History]. München, Beck. 320 p. (ger).

Bohiv, O., Zadorozhnyy V. (1999) Carpathian Ukraine (Subcarpathian Rus) in international relations ( May 1938 - March 1939). Uzhhorod, Patent. 80 p. (ukr).

Boris Yeltsin Presidential Library (BYPL). (rus).

Central Archives of the Ministry of Defence of the Russian Federation (CAMORF). (rus).

Chubar'yan A. (2008) The Eve of Tragedy: Stalin and International Crisis, September 1939 - June 1941. Moscow, Nauka. 484 p. (rus).

Circular Dispatches 1920-1935 (2002) Edvard Beneš. From the Records of the Foreign Affairs Ministry of the Czech Republic. Ed. J. Dejmek. Prague, Společnost Edvarda Beneše. 277 p. (czech). 
Deszczyński M-P. (2003) The Last Exam. Polish Army towards Czechoslovak crisis 1938-1939. Warsaw, Neriton. 202 p. (pol).

Documents and Materials of the Eve of the Second World War, 1937-1939: in two volumes. Vol. 1. November 1937 - December 1938 (1981), Moscow, Politizdat. 306 p. (rus).

Documents and Materials on History of Soviet-Polish Relations (1969) Vol. 6. 1933-1938. Moscow, Institute of Slavic Studies of the Academy of Sciences of the USSR, 432 p. (rus).

Documents of Soviet Foreign Policy. Vol. 21. 1st January - 31st December 1938. (1977). Moscow, Politizdat. 792 p. (rus).

Documents on the history of Munich agreement (1979) Moscow, Politizdat. 471 p. (rus).

Faber D. (2009) Munich: the 1938 appeasement crisis. London, Simon \& Schuster. 518 p. (eng).

Grycak Y. (2000) An Outline of the History of Ukraine. Forming of the Modern Ukrainian Nation in 19th-20th Centuries. Kyiv, Genesis. 360 p. (ukr).

History of the Great Fatherland War of Soviet Union 1941-1945, in 6 volumes. Vol. 1. The Preparation and Unleashing of War by the Imperialist States (1960) Moscow, Voenizdat. 600 p. (rus).

International Crisis od 1939 in the Interpretations of Russian and Polish Historians (2009) Moscow, Aspect Press. 479 p. (rus).

Kamiński M-K. (2001) Polish-Czechoslovak Conflict 1918-1921. Warsaw, Neriton. 467 p. (pol).

Kamiński M-K. (2003) Letter to the Editorial Board of «Dzieje Najnowsze». Dzieje Najnowsze. № 4, p. 229-231. (pol).

Kornat M. (2002) Poland of 1939 towards Ribbentrop-Molotov Pact: Problem of the German-Soviet Rapprochment in the Foreign Policy of the Second Republic. Warsaw, Polish Institute of International Affairs. 808 p. (pol).

Kornat M. (2010) State of Research on the Polish-Soviet Relationships. In: White spots - black spots: Difficult issues in Polish-Russian relations (1918-2008). Warsaw, Polish Institute of International Affairs. pp. 793-841. (pol).

Kornat M. (2015) Polish politics of memory after 1989: problems, dilemmas, postulates. In: Russia and Poland: History is common and divided. Moscow, Aspect Press. pp. 23-59. (rus).

Kudryachenko A. (2019) Carpatho-Ukraine in the plans of Hitlerite Germany. Rusin. № 57. pp. 271-293. (ukr).

Mar'ina V. (2007) Soviet Union and Czecho-Slovak Question in the World War II, 1939-1945. Vol. 1. 1939-1941. Moscow, Indrik. 448 p. (rus).

Mel'tyukhov M. (2002) Stalin's Lost Chance: Soviet Union and Fight for Europe, 1939-1941 (documents, facts, opinions). Moscow, Veche. 608 p. (rus).

Morozov S. (2004) Polish-Czechoslovak Relations, 1933-1939. What Was Hiding Behind the «Equal Distance» Policy of Minister Józef Beck? Moscow, Moscow University Press. 527 p. (rus).

Munich 1938: the Fall in the Abyss of World War II (2018) Moscow, Kuchkovo Pole. 272 p. (rus).

Nevezhin W. (1997) Syndrome of Aggressive War: Soviet Propaganda on the Eve of «Saint Fights», 1939-1941. Moscow, Airo-XX. 286 p. (rus). 
Oficyns'kyy R. (2020a) Actually on Hungarian Aggression on Carpathian Ruthenia (1938-1944). In: Oficyns'kyy R. Carpathian Ukraine: historical essays. Uzhhorod, Timpani. pp. 145-150. (ukr).

Oficyns'kyy R. (2020b). Occupation and Annexation of the Carpathian Ukraine (March-July 1939). In: Oficyns'kyy R. Carpathian Ukraine: historical essays. Uzhhorod, Timpani. pp. 60-73. (ukr).

Pavlenko O. (2008) Historiographical image of «Munich of 1938» and problems of historical memory. Munich Agreement 1938: History and Present: materials international. scientific. conf., October 15-16, Moscow6 Nauka. pp. 388-408. (rus).

Pepłoński A. (1996) Polish Intelligence in USSR. 1921-1939. Warsaw, Bellona. 392 p. (pol).

Poland in Fight for Western Europe 1920-2020. (2020). Moscow, Kuchkovo Pole. 176 p. (rus).

Putin W. (2009) Pages of history - Ground for the Mutual Grievances, or for Reconciliation and Partnership? URL: https://wyborcza.pl/1,75399,6983945 (Accessed July 24, 2020). (pol).

Resolution of the People's Deputies Congress of Soviet Union of December 24, 1989, no. 979-1 on political and legal assessment of Soviet-German Non-Aggression Agreement of 1939. URL: https://www.lawmix.ru/docs_cccp/1241. (rus).

Russian State Archive of Socio-Political History (RGASPI). (rus).

Russian State Military Archive (RGVA). (rus).

Samuś P., Badziak K., Matwiejew G. (1998) Operation «Łom». Polish Sabotage Action in Carpathian Ruthenia in the Records of the Second Department of General Staff of Polish Army. Warsaw, Adiutor. 327 p. (pol).

Solonin, M. (2011) Moscow and «Munich». Military-industrial courier. No 8 (374), March 2, 2011; No 9 (375), March 9, 2011; No 10 (376), March 16, 2011. (rus).

«Soviet Documents on Third Reich Released» (2020) https://lenta.ru/news/2020/05/21/docs/ Accessed July 27, 2020. (rus).

Soviet-Polish relations in Political Circumstances of Europe in 1930s. (2004) Moscow, Nauka. 231 p. (rus, pol).

State Archive of Russian Federation (GARF). (rus.)

Subtel'niy O. (1993) Ukraine: History. Kyiv, Libid. 720 p. (ukr).

The Year of the Crisis 1938-1939. Documents and Materials in Two Volumes Vol. 1. September 29, 1938 - May 31, 1939. (1990) Moscow, Politizdat. 562 p. (rus).

Trofymovych L., Trofymovych V. (2013) Dangerous rivalry... Ukrainian issue in foreign policy of Poland and the Soviet Union 1938-1939. Rivne, Volyn amulets. 234 p. (ukr).

Trofymovych V., Trofymovych L. (2019) Carpatho-Ukrainian aspekts of European Foreign policy during the Czechoslovakian crisis (1938-1939) Rusin. № 57. pp. 251270. (ukr).

USSR, Western Europe and World War II, 1939-1941: discussions, commentaries, thoughts. (2007) Moscow, Nauka. 486 p. (rus).

Valenta J. (2003) Letter to the Editorial Board of «Dzieje Najnowsze». Dzieje Najnowsze. № 4. pp. 227-228. (pol).

Vegesh M. (1998) Carpathian Ruthenia in the Context of the Central European Political Crisis on the Eve of World War II. Summary of Doctoral Thesis in Historical Sciences. Kyiv, Institute of History of Ukraine. 30 p. (ukr). 
Vegesh M. (2004) Augustin Voloshin and Carpathian Ukraine. Lviv, ZUKC. 414 p. (ukr).

Wierzbiański K. (1986) Beneš and Poland. Zeszyty Historyczne № 76. pp. 79-88. (pol).

Włodarkiewicz W. (2002) Before September 17, 1939: Soviet Endangerment of Polish Republic in the Assesment of the Polish Head Military Authorities 19211939. Warsaw, Neriton. 317 p. (pol).

18th Congress of All-Union Communist Party (Bolshevik). March 10-21, 1939. Stenographic Report. (1939). Moscow, Gospolitizdat. 737 p. (rus).

Yazhborovskaya I. (2015) Recent Time's Poland in Politics of History of Soviet Union and Contemporary Russia In: Russia and Poland: History is common and divided. Moscow: Aspect Press. pp. 230-247. (rus).

Żerko S. (2009) Poland and the Sudeten Crisis of 1938 In: Munich agreement of 1938: history and modernity: materials of the international scientific conference. Moscow, October 15-16, 2008. Moscow, Nauka. pp. 171 - 189 (rus).

\section{II'yushyn I.}

THE ATTITUDE OF THE USSR TO THE CZECHOSLOVAK CRISIS AND THE QUESTION OF CARPATHIAN RUS (1938-1939)

The article analyzed the position of the USSR leadership on the Central European (Czechoslovak) political crisis on the eve of World War II. It was proved that the actions of the USSR aimed at supporting Czechoslovakia were dictated primarily by the intention to fulfill their obligations under the Soviet-Czechoslovak Treaty on mutual assistance and thereby prevent serious changes in the European geopolitical configuration as a result of the military conflict, which would be to the detriment of Moscow. At the same time, it is difficult to believe only in the peaceful nature of the foreign policy activities of the USSR at a time when he was already armedly opposed to the block of fascist states in Spain, and in the Soviet country itself continued unjustified political persecution and killings.

On the other hand, the territorial annexation of Czechoslovakia, and its subsequent and final elimination, was facilitated by the policies of Great Britain and France, whose governments did little to stop the German expansion. On the contrary, by signing the Munich Agreement, they actually recognized the territory of Central and Eastern Europe as the sphere of prevailing interests of the Third Reich, and its claims as a «natural process».

Considerable attention was also paid to the place and role of Carpathian Rus in those events from the moment of the Munich Agreement and separation of the Sudetenland from Czechoslovakia by Germany on October 1, 1938 until the inclusion of the Czech Republic in the Third Reich March 15, 1939.

Germany's complete absorption of the Czechoslovak Republic and the seizure of Carpathian Ukraine by Hungary, on the one hand, finally paralyzed the possibility of intervention of the Soviet Union in this matter, but, on the other hand, gave grounds for a gradual reorientation of its foreign policy towards the Soviet-German rapprochement.

Keywords: Munich agreement of 1938, German occupation, Czechoslovak crisis, Soviet Union, Carpathian Rus. 